\title{
THE GRAIL OF ORIGINAL MEANING: USES OF THE PAST IN AMERICAN CONSTITUTIONAL THEORY*
}

\author{
Prothero Lecture \\ By Colin Kidd \\ READ 1 JULY 2015
}

\begin{abstract}
Originalist jurisprudence, which enjoins a faithful adherence to the values enshrined in the late eighteenth-century Constitution, has become a prominent feature of contemporary American conservatism. Recovering the original meaning of the Constitution is far from straightforward, and raises major issues of historical interpretation. How far do the assumed historical underpinnings of originalist interpretation mesh with the findings of academic historians? To what extent has the conservative invocation of the Founding Fathers obscured a lost American Enlightenment? Nor is 'tradition' in American constitutional law an unproblematic matter. How far does a desire to restore the original meaning of the Constitution ignore the role of 'stare decisis' [precedent] in America's common law heritage? It transpires, moreover, that the various schemes of historical interpretation in American constitutional jurisprudence do not map easily onto a simple liberal-conservative divide.
\end{abstract}

Originalism has been a controversial presence in American constitutional law since the 1980s. Reacting against the liberal 'living Constitution' jurisprudence of the Supreme Court during the Warren and Burger courts, conservatives urged fidelity to the original principles which had animated the Constitution in the later eighteenth century. According to conservatives, the Court's ultra-liberal decisions during the 1960s and 1970s had signified a double betrayal: both the overturning of enduring moral values in the name of fashionable progressive ideas, and a rejection of Constitutional authority, indeed of the very idea of the rule of law. Originalism offered itself as an obvious way of correcting the folly and perfidy of judges. An insistence on the original meaning of the Constitution provided an attractively compelling method for frustrating the agenda of a liberalism which seemed arbitrary, rootless and impulsive. However, notwithstanding this claimed contrast between unwarranted liberal innovation and originalism's deep anchorage in late eighteenth-century American history, a self-conscious originalism was not - contrary to superficial appearances - a natural outgrowth from pre-existing tradition. Rather it was more closely analogous to 'invented tradition', and displayed ostentatiously exaggerated respect for the eighteenth-century Founding.

The culture wars were part of a wider realignment in American politics. In particular, divisions over abortion, sexuality, race, militarism, crime and counter-cultural deviance contributed to the decline of the party system inherited from the New Deal era, when a Democratic coalition consisting of a Southern regional bloc and northern blue collar interests confronted a privileged but far-from-illiberal Republican party. During the latter part of the twentieth century moral and cultural issues led to a redrawing of the social and regional maps of American politics. The irrepressible dynamism of popular evangelicalism - alongside American Catholicism - did much to invigorate the anti-counter-culture of the New Right. Moreover, radical reform lacked a democratic mandate, and was associated rather with an interventionist federal judiciary which, in the eyes of its critics, used a rights agenda to trump local majorities. Not only did the decision in Roe v Wade (1973) effectively legalize abortion during the first two trimesters of a pregnancy, but it seemed to mark the culmination of a series of usurpations - so its critics reckoned - by the Court of the terrain of legislatures. Engel v

\footnotetext{
* I should like to thank John Hudson for remarks on an earlier draft of this piece.

${ }^{1}$ E. Hobsbawm and T. Ranger (eds), The Invention of Tradition (Cambridge, 1983).
} 
Vitale (1962) controversially outlawed school prayer, while Abington v Schempp (1963) excluded Bible-reading from the classroom, and eventually the Lemon Test, introduced in Lemon v Kurtzman (1971), effectively prohibited not only laws which gave support to religion, but also the excessive 'entanglement' of state and church. Furthermore, a series of decisions - in Mapp v Ohio (1961), Gideon v Wainwright (1963), Miranda v Arizona (1966) - seemed to side with the rights of criminal defendants against the forces of law and order. Furman v Georgia (1972) placed a moratorium on capital punishment as an unconstitutional infringement of the Eighth Amendment's ban on 'cruel and unusual punishment'. Less immediately explosive, Griswold v Connecticut (1965), which overturned a state law banning contraceptives, discovered a controversial zone of 'privacy' within the 'penumbras' of the Bill of Rights. ${ }^{2}$ Concerns about the undemocratic manner in which change had occurred compounded alarms over the character of the changes themselves. It was bad enough, as it seemed to conservatives, that liberal elites were using the Bill of Rights to ride roughshod over public opinion. But what if the liberal judiciary's invocation of the Constitution was utterly spurious? What if abortion, say, or sexual privacy, were not historically encompassed within the heritage of American liberties? What if the Founders were not unduly worried, say, about the death penalty? The ferocity of the anti-counter-cultural reaction in America owes much to the feeling that a liberal judiciary had duped the general public. Understandably, given the totemic importance of the Constitution and Bill of Rights, eighteenth-century history has become a theatre of the culture wars.

This is further compounded by the reverential attitude of many Americans, Democrats as well as Republicans, towards the Founding Fathers of the nation and the institutions they created. The wisdom of the Founding Fathers is a largely unquestioned axiom of American two-party politics. To question the glorious perfection of the Constitution, to pinpoint blemishes here and there in its design, is bad form, a breach of a commonly understood and shared etiquette. Needless to say, this attitude does not prevail in all quarters of American life. Most obviously, ideological critiques have come from Marxists, ${ }^{3}$ African-Americans, ${ }^{4}$ feminists and from radical legal realists in the Critical Legal Studies movement, ${ }^{5}$ who located manifest flaws in American institutions, and from a few outspoken jurists and political scientists who have drawn attention to the undemocratic features of the Constitution. ${ }^{6}$ Nevertheless, these groups, though vociferous within the academy, are marginal to mainstream opinion, where the Founders retain a quasi-religious status. As the sociologist Robert Bellah has shown, the cult of the Founders is part of America's 'civil religion', a form of ancestor worship which in a secular state substitutes for a more conventional kind of established church. ${ }^{7}$ Indicative of the demigod-like esteem in which the Founders are held is What Would the Founders Do? (2006) by Richard Brookhiser, a senior editor at the ultra-conservative National Review, which applied late eighteenth-century wisdom to modern-day problems of which the Founders could never have dreamt. What, a straight-faced Brookhiser asked, would the Founders say about stem-cell research? How would the Founders have fought the war on drugs? What would the Founders do about weapons of mass destruction? ${ }^{8}$

\footnotetext{
2381 U.S. 479 (1965).

${ }^{3}$ Cf. M. Horwitz, The Transformation of American Law, 1780-1860 (Cambridge MA, 1977).

${ }^{4}$ Cf. R. Perlstein, The Invisible Bridge: the Fall of Nixon and the Rise of Reagan (New York, 2014), 262-3, for Congresswoman Barbara Jordan's famous speech to the House Judiciary Committee during Watergate: 'But when [the Constitution] was completed on the seventeenth of September in 1787, I was not included in that "We, the people."... I felt somehow for many years that George Washington and Alexander Hamilton just left me out by mistake.' Yet, even this critical preamble notwithstanding, Jordan's speech went on to celebrate the Constitution.

${ }^{5}$ M. Tushnet, 'Critical Legal Studies and Constitutional Law', Stanford Law Review 36 (1984), 623-47.

${ }^{6}$ R. A. Dahl, How Democratic is the American Constitution? (New Haven, 2002); Sanford Levinson, Our Undemocratic Constitution (Oxford and New York, 2006).

${ }^{7}$ R. Bellah, 'Civil Religion in America', [originally published in Daedalus (winter, 1967)], reprinted in R.E. Richey and D.G. Jones (eds), American Civil Religion (New York, 1974), 21-44.

${ }^{8}$ R. Brookhiser, What would the Founders do? Our Questions, their Answers (New York, 2006).
} 
The cult of the Founders frustrates dispassionate analysis of the Constitution. It means that the Constitution is regarded as enjoying sacrosanct status, akin more to the Ten Commandments than to a set of explicitly amendable rules for self-government. Certainly, it seems clear from Article V of the Constitution that the Founders never intended the Constitution - which they recognised as a product of political compromise - to be set in aspic. As Madison himself wrote in Federalist no. 37, 'a faultless plan was not to be expected'. ${ }^{9}$ Yet the Founders were not to know that the United States would grow to a scale which made the Article $\mathrm{V}$ amendment process - with its requirements of twothirds super-majorities in both houses of Congress (or a national convention requested by two-thirds of the States) and ratification in three-quarters of the States - so hard to accomplish. The difficulty of amending the Constitution only serves to reinforce the notion that the handiwork of the all-wise Founding Fathers was to be preserved largely unchanged forever. ${ }^{10}$

Originalism had its beginnings in Richard Nixon's pledge during his 1968 campaign to appoint only strict constructionists to the Court. Today academic jurists stress that strict construction a method for interpreting any text - and the original intention behind the text are not synonymous; nevertheless, in the crude hurly-burly of political campaigning Nixon's commitments prefigured the later turn to originalism proper. Nixon had grave difficulty finding professionally credible jurists who dissented from the idea of the 'living constitution'. His first nominees to the Supreme Court Clement Haynsworth and G. Harrold Carswell - were rejected by the Senate. While Nixon did secure the appointment of William Rehnquist to the Court, his other successful nominees included Harry Blackmun, the author of the ultra-liberal decision in Roe $\mathrm{v}$ Wade. There were further wry incongruities, for the principal pioneer of an originalist approach in legal history during the 1970s was a convinced opponent of Nixon. Raoul Berger (1901-2000) had made his name as an uncompromising opponent of Nixon's exaggerated claims of Executive Privilege during the Watergate crisis, ${ }^{11}$ but became an unlikely standard-bearer for an originalist interpretation of the Fourteenth Amendment of 1868 with his controversial book, Government by Judiciary (1977). Berger has been labelled a conservative, but his jurisprudence was sui generis and defied partisan categories. The early glimmerings of originalism Berger inspired in the late 1970s immediately provoked a major academic counterblast from Paul Brest, a proponent of critical legal studies ${ }^{12}$ : a sophisticated critique of originalism's claims which preceded the full-fledged emergence of an originalist jurisprudence in conservative circles. ${ }^{13}$

For it was only during the 1980s that the perceived disjunction between the wisdom of the eighteenth-century Founders and the reckless irresponsibility of the Warren and Burger Courts provoked a more decisive conservative turn to originalism. In 1982 Steve Calabresi founded the Federalist Society. Calabresi, then a law student at Yale, later a law professor at Northwestern University, began the Federalist Society along with some fellow law students. Although the Society emerged out of disenchantment with the ultra-liberal consensus of the professoriate, it was not narrowly ideological and promoted open debate. Indeed, Calabresi was himself a Reagan Democrat. Nevertheless, conservative originalism - though not a straitjacket of orthodoxy - was the dominant motif of the Federalist Society. Chapters rapidly sprang up at other law schools, and eventually by 2001 there were chapters at over two hundred law schools. Meanwhile, there were also around thirty thousand lawyers enrolled in professional chapters. ${ }^{14}$

In 1985 Edwin Meese III (b. 1931), Ronald Reagan's new Attorney-General, issued an originalist counter-blast to the liberal judiciary. In a speech to the American Bar Association he

\footnotetext{
${ }^{9}$ The Federalist (ed. T. Ball, Cambridge, 2003), 169.

${ }^{10}$ By contrast, see D. Lazare, The Frozen Republic: How the Constitution is Paralyzing Democracy (New York, 1996).

${ }^{11}$ R. Berger, Executive Privilege: a Constitutional Myth (Cambridge MA, 1974).

${ }^{12}$ L. Kalman, The Strange Career of Legal Liberalism (New Haven, 1996), 109.

${ }^{13}$ P. Brest, 'The Misconceived Quest for Original Understanding', Boston University Law Review 60 (1980), 204-38.

${ }^{14}$ S. Teles, The Rise of the Conservative Legal Movement (Princeton, 2008), 135-80.
} 
proclaimed his - and the administration's adherence - to a 'jurisprudence of original intention'. Meese specifically complained about the 'misuse of history' implicated in an 'activist jurisprudence' which imported its own whims into the Constitution. What was the point of the Constitution, he argued, if it were traduced by self-indulgent judges whose 'chameleon jurisprudence' meant its 'changing color and form in each era'. ${ }^{15}$ Meese soon found himself in a spat with Justice William Brennan (1906-97), the leading liberal on the Supreme Court, though, Brennan was ironically - like Earl Warren himself - the appointee of a Republican President, Eisenhower. In response to Meese, Brennan invoked the 'transformative purpose' of a text characterised by 'majestic generalities and ennobling pronouncements'. Only originalists could be so obtuse as to construe the Constitution so narrowly as to overlook 'the constitutional vision of human dignity' embodied in the Bill of Rights. Brennan also pointed to the intractable difficulties which inhered in a jurisprudence of 'original intention'. Was any coherent intention to be found in 'a jointly drafted document drawing its authority from a general assent of the States'? The apparent 'self-effacing deference' of originalists to the Founders was, Brennan reckoned, an arbitrary and presumptuous 'arrogance cloaked as humility'. ${ }^{16}$

Matters came to a head in the summer of 1987 - the bicentennial of the Constitution - when Ronald Reagan nominated a notorious originalist, Robert Bork (1927-2012), for the seat vacated by Justice Lewis Powell, the 'swing' justice on the Supreme Court. The major concern of Bork's mentor at Yale, Alexander Bickel (1924-74), had been the injudicious overreach he observed in the decisions of the Warren Court. In his influential book The Least Dangerous Branch (1962) Bickel framed the central problem in contemporary constitutional theory, 'the counter-majoritarian difficulty'. The Court's powers of judicial review - its capacity to strike down unconstitutional laws made by the duly elected legislative branches at the State and federal level - needed to be exercised sparingly, for fear of raising issues of legitimacy. The Court's role, as Bickel saw it, was to complement - and sometimes correct - majoritarian democracy, but without cocking a snook at democratic standards. ${ }^{17}$ Bork elaborated Bickel's misgivings into a form of originalism which liberals found threatening. Was Bork, they alleged, going to turn back the clock, curtailing recently won sexual freedoms and rights of expression? It so happened that Bork, as Solicitor-General under Nixon in 1973, had, at a moment of dire crisis in the Department of Justice, executed Nixon's order to fire Archibald Cox, the special prosecutor in the Watergate affair, who was pursuing Nixon relentlessly for access to presidential tapes. ${ }^{18} \mathrm{~A}$ bogeyman to liberals, though an eminently qualified jurist of great intellectual distinction, Bork was rejected by 58 votes to 42 in the Senate. ${ }^{19}$ Reagan then nominated Douglas Ginsburg (b. 1946), another originalist, who took the view that the original Constitution had been in abeyance since the Court's acceptance of the New Deal from 1937-8 onwards, what Ginsburg later referred to as the 'Constitution-in-exile'. ${ }^{20}$ However, Ginsburg ran into difficulties when it came to light that he had dabbled in marijuana with his students while a junior faculty member at Harvard, and his nomination was withdrawn. Eventually, a more liberal non-originalist conservative, Anthony Kennedy, was successfully confirmed in the seat vacated by Powell.

Notwithstanding this setback an originalist phalanx was already forming on the Court. Rehnquist had been elevated to Chief Justice in 1986, and in the same year another originalist, Antonin Scalia (1936-2016), was easily appointed to the Supreme Court, confirmed - strange as it might now seem given his later reputation as an originalist bruiser - by a vote of 98-0 in the Senate.

\footnotetext{
${ }^{15}$ E. Meese III, 'Interpreting the Constitution', in J. Rakove (ed.), Interpreting the constitution: the Debate over Original Intent (Boston, 1990), 13-21, esp. 17, 20.

${ }^{16}$ W. J. Brennan Jr., 'The Constitution of the United States: Contemporary Ratification', in Rakove (ed.), Interpreting, 23-34, at 23, 25, 28, 31.

${ }^{17}$ A. Bickel, The Least Dangerous Branch: the Supreme Court at the Bar of Politics (1962: $2^{\text {nd }}$ edn., New Haven, 1986).

${ }^{18}$ S. Kutler, The Wars of Watergate (1990: New York, 1992), 407.

${ }^{19}$ For Bork's post-mortem on the affair and its wider juridical significance, see Bork, The Tempting of America: the Political Seduction of the Law (New York, 1990).

${ }^{20}$ D. Ginsburg, 'Delegation Running Riot', Regulation 1 (1995), 83-7, at 84.
} 
More controversially, in 1991, Clarence Thomas (b. 1948) - nominated by George Bush Snr - joined this ultra-conservative grouping on the Court.

Nevertheless, there is no single agreed originalist method of reading the Constitution, whether in the law schools or among originalist Justices on the Court. Originalism contains many mansions, and the quest for original meaning is not as straightforward as Meese and others have tended to assume. Although originalists tend to promote their brand of interpretation as the only honest method of approaching the Constitution - simple common sense in fact - originalism, when examined more closely, turns out to be composed of various overlapping, but distinct and potentially competitive, strategies. According to Lawrence Solum, originalism has 'evolved' into 'a family of related theories'. ${ }^{21}$

What, then, are the main varieties of originalism? At the outset, it is important to note that although originalism is often referred to as 'original intent', original intent turns out to be only one genre among several different types of originalist interpretation. The focus of original intent is on the intentions of the Founding generation which lie behind the words of the Constitution. What did the framers intend by the words and phrases they used? Needless to say, the objective of original intent is far-from-scientific, but relies on the other hand on what historians would recognise as the historical imagination, the ability to reconstruct the mental world of the late eighteenth century. Though it helps here to ransack eighteenth-century dictionaries, philology in itself is insufficient, and needs to be supplemented, it is recognised, by a wider appreciation of social forms and practices. Dennis Goldford describes this version - focussed on the original intent of the framers - as 'hard' originalism, to be distinguished from a 'soft' originalism, based on the accepted meanings of the Constitution understood by its ratifiers in the state ratifying conventions and its wider public meaning in contemporary discourse. ${ }^{22}$ Soft originalists tend to rely on the text of the Constitution itself rather than on the intentions which lay behind it. Yet textualism itself is far from straightforward and encompasses several different approaches to the Constitution. The most obvious kind of textualism is 'clause-bound' analysis, which takes each particular clause on its own. However, a 'structuralist' variant of textualism argues that individual clauses need to be considered in relation to the text of the Constitution as a whole. Potential inconsistencies or ambiguities between clauses can then be clarified with respect to the overall architecture of the Constitution. 'Purposive' textualism, on the other hand, considers the text in terms of the noble aspirations which it enshrines. ${ }^{23}$

Clarence Thomas is the only Supreme Court Justice to employ a jurisprudence of original intent, though Ralph Rossum has demonstrated that, strictly speaking, original intent forms only one pillar of Thomas's compound doctrine which Rossum terms 'original general meaning', drawn from original intent, as well as the original understanding and public meaning of the text. ${ }^{24}$ Thomas's originalist immersion in the Founding era verges on the bizarre; not only spectacularly erudite, but also at times gruesome and ghoulish. For instance, in Baze v Rees (2008) the Supreme Court upheld Kentucky's procedures for administration of lethal injections, and rejected complaints that it violated the Eighth Amendment's ban on 'cruel and unusual punishments'. Thomas's concurring opinion in Baze drew on a wide variety of sources, including modern historical scholarship, to clarify what the Eighth Amendment had proscribed. Some procedures were recognised as 'intensifying' a death sentence, including gibbeting, dissection, burning at the stake, embowelling, beheading and quartering, which constituted, Thomas reckoned, 'aggravated forms of capital punishment'. Thomas also ransacked contemporary dictionaries - including those of Samuel Johnson and Noah Webster to capture the 'ordinary meaning' back then of the word 'cruel'. What was forbidden was 'intentional

\footnotetext{
${ }^{21}$ L. Solum and R. Bennett, Constitutional Originalism: A Debate (Ithaca, NY, 2011), 2

${ }^{22}$ D. Goldford, The American Constitution and the Debate over Originalism (Cambridge, 2005), 9.

${ }^{23}$ For the varieties of textualism, see J. O’Neill, Originalism in American Law and Politics (Baltimore, 2005), 4-5.

${ }^{24}$ R.A. Rossum, Understanding Clarence Thomas: the Jurisprudence of Constitutional Restoration (Lawrence KS, 2014), esp. 12-15.
} 
infliction of gratuitous pain'. The notion that execution needed somehow to be 'anesthetized' to be Constitutional found no warrant in Thomas's jurisprudence of original understanding. ${ }^{25}$

Although Antonin Scalia was Justice Thomas's closest ally on the Supreme Court over the past twenty years, he expressed a kind of head-shaking contempt for the futility of Thomas's misguided originalism. In Scalia's view, the attempt to recover original intent was doomed to failure and, worse, to a kind of subjectivity of the sort it attempts to evade. The only sure ground, Scalia reckoned, is the text of the Constitution itself. Its general acceptance in the ratification process suggests that it embodied a set of widely-shared meanings (whatever the intentions of the framers). This is the logic behind the jurisprudence of original meaning, which soon supplanted original intent as the core doctrine of conservative originalism. ${ }^{26}$

For all his notorious bombast, Scalia - unlike Thomas - recognised that there are other claims of tradition besides the original Constitution. Traditions collide, and stare decisis - the authority of precedent in case law - presents a rival source of historic legitimacy. Thomas, on the other hand, appears unconstrained by precedent when he perceives that existing traditions of judicial interpretation have betrayed the original intention behind the Constitution. Willingness of this sort to overturn well-established precedent for the sake of original meaning verges on a kind of judicial activism, arguably a variant of the phenomenon which it criticises. Scalia's originalism was, he conceded, necessarily limited by his lawyerly respect for stare decisis. 'In its undiluted form', Scalia acknowledged, originalism is a 'medicine that seems too strong to swallow' ${ }^{27}$ Scalia was far from alone in this deference to extra-originalist continuity. In his closing statement to the Senate Judiciary Committee Bork made clear that stare decisis inevitably imposed limitations on what an originalist jurisprudence might reasonably hope to achieve. Bork recognised 'a number of important precedents that are today so woven into the fabric of our system that to change or alter them would be, in my view, unthinkable. ${ }^{28}$ Yet, one should not exaggerate Scalia's pragmatism. Even the ultra-conservative Justice Samuel Alito has playfully mocked the anachronistic excesses inherent in a jurisprudence of original meaning. During oral discussion of Schwarzenegger [later Brown] v Entertainment Merchants Association, which dealt with violence in video games, Alito unhelpfully summarised what he took to be Scalia's line of questioning: 'Well, I think what Justice Scalia wants to know is what James Madison thought about video games. Did he enjoy them?' ${ }^{29}$

The division between Thomas and Scalia exemplifies the main axis of division within conservative originalism, but it does not exhaust the range of purported originalisms. Indeed, the prominent jurist and philosopher, Ronald Dworkin, tried to navigate by means of an originalist method to a liberal destination. Dworkin drew a sharp distinction between his own scheme of 'semantic originalism' (in effect a brand of purposive textualism, in which the text embodied 'abstract moral standards'), which he contrasted with 'expectation originalism', the notion that the text possessed merely the precise legal force that its framers expected it to have. ${ }^{30}$ Moral philosophy has, of course, moved on since the late eighteenth century; therefore, a recalibration of the ethical aspirations of the Founders - say, for example about the changing connotations of the "cruel and unusual punishments' unspecified, perhaps deliberately, in the Eighth Amendment - meshed easily with the original motivating principles behind the Constitution. On the other hand, Dworkin's critics

\footnotetext{
25553 U.S. 35 (2008).

${ }^{26}$ For the evolution of Scalia's jurisprudence of original meaning and its insistent distance from the originalism of Bork and Thomas, see B.A. Murphy, Scalia: a Court of one (New York, 2014), esp. 111-12, 126, 143, 153, 164, 246-7, 369.

${ }^{27}$ A. Scalia, 'Originalism: the Lesser Evil', University of Cincinnati Law Review 57 (1989), 849-65, at 861.

${ }^{28}$ R.E. Shaffer (ed.), The Bork Hearings (Princeton, 2005), 161.

${ }^{29} \mathrm{http}: / /$ www.supremecourt.gov/oral arguments/argument transcripts/08-1448.pdf (at 17).

${ }^{30}$ R. Dworkin, Freedom's Law: the Moral Reading of the American Constitution (Oxford, 1996); Dworkin, 'Comment', at 119-26, in A. Scalia, A Matter of Interpretation: Federal Courts and the Law (ed. A. Gutman, Princeton, 1997); Dworkin, Justice in Robes (Cambridge MA, 2006), 29-30, 117-39.
} 
deny that this pseudo-originalist outlook bore any fidelity to the Constitution. ${ }^{31}$ An alternative attempt to square the originalist circle on liberal terms is Jack Balkin's refusal to accept the premiss that originalism and the 'living Constitution' are intrinsically incompatible. Instead, Balkin has espoused a hybrid 'living originalism', which depends on a recognition of the enduring structures of the Constitution - what he calls 'framework originalism' - complemented by an openness to evolving ethical standards. ${ }^{32}$

More commonly, however, liberal jurists have confronted originalism head on, explaining why, in their view, it rests on marshy foundations. Few were as alert to the historical dimension as Brest. Nonoriginalist 'translation' of the Founders' intentions, he insisted, was a necessary part of Constitutional interpretation; otherwise Congress would not be able to 'regulate any item of commerce or any mode of transportation that did not exist in in 1789; the First Amendment would not protect any means of communication not then known.' Moreover, he was sufficiently aware of the way historians operated to perceive that strict intentionalism - contrary to the expectations of originalist jurists, who aimed at settled meaning - threatened to inject instability into the law. Historians discover new documents, and reinterpret otherwise familiar sources. Moreover, 'we have witnessed enough dramatic revisions of social and political history,' Brest warned, 'to be sure that the past itself is not about to stand still. ${ }^{33}$

Historians have been less prominent in the wars over originalism, with the major exception of Jack Rakove, who outlined the 'perils of originalism' in his Pulitzer Prize-winning book Original Meanings: Politics and Ideas in the Making of the Constitution (1996).$^{34}$ Indeed, it was Rakove who coined the phrase 'the Holy Grail of original meaning' to capture the unattainability of the objective originalists pursued. ${ }^{35}$ The originalist enterprise is doomed to failure - intellectual failure at least Rakove reckoned, because it seeks to find 'determinate meanings' at a moment of Constitutionmaking which was 'dynamic and creative, and thus uncertain'. Contested ambiguity cannot be reliably transmuted into fixed meaning. That kind of alchemy is beyond even the powers of constitutional jurists. This is because, according to Rakove, the politics of Constitution-making and then ratification produced a 'range of understandings' which amounted to 'rather less than a consensus.' Indeed, Rakove calculates that there were approximately two thousand protagonists who participated in the various conventions that first framed, then ratified, the Constitution. Divining a single original intent or even a shared understanding amongst this varied cast is not so much fraught with difficulty, as it is an outright chimera. ${ }^{36}$

However, jurists themselves come to adopt a more historically sensitive approach to the Constitution, and two of the most subversively anti-originalist reinterpretations of American constitutional history have come from the Yale Law School, from Bruce Ackerman (b. 1943) and Akhil Reed Amar (b. 1958). Ackerman undermines the claim of originalism by unmasking the Constitution itself as an unconstitutional usurpation on the previous constitution - the Articles of Confederation, which preceded it. ${ }^{37}$ The Founders' achievement, he insists, very persuasively, rested on 'flagrant illegalities'. ${ }^{38}$ The sole purpose of the Convention was 'revising' the Articles of Confederation, under whose rules any changes required unanimity of agreement. A new Constitution was not part of the Convention's remit, and what actually transpired at Philadelphia was an 'illegal

\footnotetext{
${ }^{31}$ K.E. Whittington, 'Dworkin's "Originalism”: the Role of Intentions in Constitutional interpretation', Review of Politics 62 (2000), 197-229.

32 J. Balkin, Living Originalism (Cambridge MA, 2012).

${ }^{33}$ Brest, 'Misconceived', 221, 231.

${ }^{34}$ Jack Rakove, Original Meanings: Politics and Ideas in the Making of the Constitution (1996: New York, 1997), 3.

35 Ibid., 10 .

${ }^{36}$ Ibid., 6, 8, 10.

${ }^{37}$ B. Ackerman, We the People vol. I Foundations (Cambridge, MA, 1991).

${ }^{38}$ B. Ackerman, 'Our Unconventional Founding', University of Chicago Law Review 62 (1995), 475-573, at 476.
} 
initiative'. According to Ackerman, what the draft Constitution at Philadelphia amounted to was 'ten delegations [ie those present throughout the Convention] urging nine states to bolt a solemn agreement ratified by all thirteen' ${ }^{39}$ But somehow a 'bandwagon dynamic' took over, and the Founders forged a new and binding Constitution from their blatant disregard of the old one ${ }^{40}$ His colleague Amar rejects Ackerman's reading of the original unconstitutional deviance which lurks behind the Constitution of 1787. Instead Amar emphasises that the Articles of Confederation had not established a new constitutional order among the thirteen states. The Articles, according to Amar, amounted to no more than a treaty. ${ }^{41}$

Nevertheless, the Founding was not the only un-Constitutional moment in Ackerman's twin-track interpretation of American history. ${ }^{42}$ The Constitution, Ackerman argues was not binding at all times and in all circumstances. The Constitution provided a compelling framework for law and governance, except at moments of crisis, when the United States experienced what Ackerman terms, somewhat euphemistically, 'unconventional innovation and democratic renewal'. ${ }^{43}$ In other words, at certain times, politicians - in the name of 'the people' - rode roughshod over the rules prescribed in the Constitution. Apart from the Founding itself, the other two examples of such crises in American history were 'the unconventional ratification' 44 of the post-Civil War Amendments, or 'amendmentsimulacra', ${ }^{45}$ in the late 1860 s, and the implementation of the New Deal in the 1930s. However, Ackerman insists, neither moment of crisis amounted to a revolution. On each occasion, reformers 'broke the rules without seeking to destroy the entire institutional framework' ${ }^{46}$ At a time of crisis, there was a reversion to popular sovereignty to refit and stabilise the ship of state. However, Ackerman's thesis made constitutional theory a much more treacherous business than originalists imagined. Far from being an uninterrupted story of Constitutional continuity, America's Constitutional heritage was one of punctuated equilibrium.

Amar is the polar twin of Clarence Thomas, an anti-originalist, but just as concerned to recover the authenticity of late eighteenth-century jurisprudence and keenly aware of the wider ideological significance of seemingly antiquarian truffle-hunting. Amar's historical researches turn the Constitution, and especially the Bill of Rights, inside out. Amar presents a defamiliarised Bill of Rights, which was not a guarantee of 'rights' as we currently understand them. Rather the modern emphasis on rights has caused jurists to overlook the majoritarian character of the Bill of Rights, which was composed of twelve, not ten items. Once the Bill of Rights is viewed in its entirety, including its first the two unsuccessful items (concerning the size of electoral districts and congressional remuneration), and the so-called First Amendment is relegated to third place in the initial ensemble, it comes more clearly into focus as a quasi-governmental blueprint outlining the infrastructural underpinnings of republican self-rule. In other words, the document - contrary to received assumptions - is largely about governmental structures, not about individual rights as such. In Amar's interpretation the Bill of Rights, as initially conceived, provided guarantees for intermediary institutions in the individual States - such as churches, militias and juries - which contributed to the inculcation of civic virtue and the formation of good republican citizens. ${ }^{47}$

Here Amar's work intersected with another trend in liberal jurisprudence, the recovery of classical republicanism. By a curious coincidence, conservative originalists were not the only group to

\footnotetext{
${ }^{39}$ Ibid., 481.

${ }^{40}$ Ibid., 568. Columbia Law Review 94 (1994), 457-508, at 462-9, 489, 507.

${ }^{42}$ See Ackerman, We the People vol. II Transformations (Cambridge MA, 1998).

${ }^{43}$ Ackerman, 'Unconventional', 573.

${ }^{44}$ Ibid., 571.

45 Ackerman, We the People vol 1: Foundations, 51.

46 Ibid., 569.

${ }^{47}$ A. R. Amar, The Bill of Rights (New Haven, 1998).
}

${ }^{41}$ A.R. Amar, 'Of Sovereignty and Federalism', Yale Law Journal 96 (1987), 1425-1520, at 1446-8; Amar, 'Philadelphia revisited: Amending the Constitution outside Article V', University of Chicago Law Review 55 (1988), 1043-1104, at 1048; Amar, 'The consent of the governed: Constitutional amendment outside Article V', 
turn during the 1980s towards the restoration of eighteenth-century values. So too did an emerging movement among liberal constitutional theorists, most prominent among them Cass Sunstein (b. 1954) and Frank Michelman (b. 1936), who used the recent historiography of late eighteenth-century America to launch what has been termed a 'republican revival' ${ }^{48}$ This phenomenon is one which historians acquainted with the celebrated works of Bernard Bailyn (b. 1922), ${ }^{49}$ Gordon Wood (b. 1933) $)^{50}$ and John Pocock (b. 1924) ${ }^{51}$ might expect to find familiar. ${ }^{52}$ However, they would be wrong. The republicanism of the jurists bears strangely little resemblance to the republican themes analysed in the historiography. Whereas Bailyn, Wood and Pocock emphasised the place of participatory virtue and fear of corruption in the agenda of classical republicanism, its supposed revivalists invoke deliberation, equality and popular majoritarian sovereignty as its principal characteristics. There is, moreover, a further ironic dissonance. The historical recovery of republicanism was an outgrowth of the contextualist revolution in the history of political thought. ${ }^{53}$ What mattered to contextualists was the precise idioms of debate in a specific time and place. The past was a foreign country; and there was no expectation that the arguments of the nowadays obscure eighteenth-century pamphleteers discussed by Bailyn and Wood would find any purchase in the present. In the event, the republicanism which Sunstein and the revivalists used to refurbish late twentieth-century liberalism had been burnished beyond recognition.

Understandably, observers questioned the ideological coherence of the republican revival. According to the intellectual historian Daniel Rodgers, republicanism became during the 1980s a kind of 'short-hand for everything liberalism was not. ${ }^{54}$ Among the most acute critics of the republican revival was Richard Fallon of Harvard Law School. Fallon recognised that the restoration of an eighteenth-century classical republican ideology was not 'practicable'. What had once been possible in the 'context of relatively small homogenous communities' was a most unlikely candidate for revival in the radically different 'social conditions' of the late twentieth century. Therefore, what was on offer was a 'watery version' of the original, 'reformulated' to take account of modern needs and expectations. In particular, the revivalists aimed to restore republican ideals without sacrificing recently won freedoms such as the right to privacy; a blatant contradiction, according to Fallon, for the classical republican emphasis on the virtues of the citizenry seemed all-too-compatible with legislation on morals. ${ }^{55}$

There was, however, one aspect of the Constitution where eighteenth-century perspectives did indeed clarify matters, namely the Second Amendment, whose strange, convoluted clauses were until recent decades - considered by jurists an 'embarrassing ${ }^{56}$ and anachronistic hangover from the eighteenth century: 'A well-regulated militia, being necessary to the security of a free state, the right of the people to keep and bear arms, shall not be infringed.' The insights of classical republican

\footnotetext{
${ }^{48}$ Both contributed to the special issue of the Yale Law Journal on republican theory: C. Sunstein, 'Beyond the Republican Revival', Yale Law Journal 97 (1988), 1539; F. Michelman, 'Law’s Republic', Yale Law Journal 97 (1988), 1493.

${ }^{49}$ B. Bailyn, The Ideological Origins of the American Revolution (Cambridge MA, 1967); Bailyn, The Origins of American Politics (New York, 1968).

${ }^{50}$ G. Wood, The Creation of the American Republic 1776-1787 (1969: New York, 1972)

${ }^{51}$ J. G. A. Pocock, The Machiavellian Moment (Princeton, 1975).

${ }^{52}$ See, amidst a vast literature, R. Shalhope, 'Toward a Republican Synthesis: the Emergence of an Understanding of Classical Republicanism in American Historiography', William and Mary Quarterly $3^{\text {rd }}$ ser. 29 (1972), 49-80; Shalhope, 'Republicanism and Early American Historiography', William and Mary Quarterly $3^{\text {rd }}$ ser 39 (1982), 334-56; L. Banning, The Jeffersonian Persuasion (Ithaca NY, 1978); D. McCoy, The Elusive Republic (Chapel Hill, 1980).

${ }^{53}$ Cf. Q. Skinner, 'Meaning and Understanding in the History of Ideas', History and Theory 8 (1969), 3-53.

${ }^{54}$ D. Rodgers, 'Republicanism: the Career of a Concept', Journal of American History 79 (1992), 11-38, at 33

${ }^{55}$ R. Fallon, 'What is Republicanism, and is it Worth Reviving?' Harvard Law Review 102 (1988-9), 16951735 , esp. at 1699, 1723, 1733-4.

${ }^{56} \mathrm{Cf}$ the rehabilitation from condescension in S. Levinson, 'The Embarrassing Second Amendment', Yale Law Journal 99 (1989), 637-59.
} 
historiography on the educative role of militia service and the dangers of standing armies helped to parse the meaning of the Second Amendment - but only within the law schools. ${ }^{57}$ For classical republicanism has left scarcely a mark on the wider public debate - dominated by the National Rifle Association, hunters and proponents of gun control - or on the courts, where a narrow fixation on the right of individuals to bear arms inhibits a more sensitive appreciation of the Second Amendment as a republican heirloom.

Tensions of this sort between academia and the courts are inevitable. Even where the judiciary - as in the case of Thomas - is up to speed with historical scholarship, history is pressed into the service of judicial decision-making. In the courts the aimless reconstruction of context and curiosity-driven research yield - understandably enough - to the imperatives of legal reasoning. Many leading jurists are, in fact, sheepishly conscious of the danger of lapsing into what is termed 'law office history', an accurate if pejorative label which serves to distinguish the disinterested salvage of the past, replete with all its messy contradictions and complexities, from historical research as a tool of advocacy. ${ }^{58}$ Jurists are sensitized to the difference between lawyers' history and historians' history, though in practice they resort to the former. ${ }^{59}$

Nevertheless, it matters enormously how the past is framed; and here there is a significant disjunction between academic history and the perception of the late eighteenth century in the public realm. In the latter the conservative cult of the Founders tends to obscure the phenomenon of the American Enlightenment - well-established in the academic literature - from which the Constitution emerged. Historians recognise that the idea of a complex Constitutional mechanism was the greatest achievement of an American Enlightenment which amplified and extended the early Enlightenment quarrel of the Ancients and the Moderns. The Founders were Moderns, conscious that modernity possessed certain insights unavailable to the Ancients. The Constitution - indebted to the mechanistic science pioneered in the seventeenth century - was conceived as a machinery of checks, balances and separated powers which far surpassed the wisdom enshrined in the traditional Aristotelian conception of politics. ${ }^{60}$ Moreover, while conservatives fondly assume that the Founders were devout Protestant patriarchs, academic research suggests that Deism and other forms of anti-Trinitarian heterodoxy were influential in the worldview of the late eighteenth-century political elite ${ }^{61}$ Here differences of register have substantive real-world consequences in constitutional law. During the 1980s liberal separatists and conservative non-preferentialists debated the original definition of what the late eighteenth century understood by the term 'establishment of religion' ${ }^{62}$ banned - or seemingly banned - in the First Amendment of the Bill of Rights. Did the Founders mean to prohibit all forms of state-sponsored religious organisation ${ }^{63}$ or only forms where one denomination enjoyed special privileges? In other words, as some historically-sophisticated conservatives maintained, was it possible to have a system of non-preferential state support for religion in general which would not amount to what the Founders would have called an 'establishment'? ${ }^{64}$

However, we should not be too quick to enlist the enlightened Founders on the liberal side in the culture wars. The American Enlightenment - as it has been reconstructed since the pioneering

\footnotetext{
${ }^{57}$ D. Williams, The Mythic Meanings of the Second Amendment (New Haven, 2003); S. Cornell, A WellRegulated Militia (New York, 2006).

${ }^{58}$ Cf. A.H. Kelly, 'Clio and the Court: an Illicit Love Affair', Supreme Court Review (1965), 119-58.

${ }^{59}$ Cf. N.M. Richards, 'Clio and the Court: a Reassessment of the Supreme Court's Uses of History', Journal of Law and Politics (1997), 809-77; M.S. Flaherty, 'History “Lite” in Modern American Constitutionalism', Columbia Law Review 95 (1995), 523-90; Kalman, Strange Career.

${ }^{60}$ D. Wootton, 'Introduction', in Wootton (ed.), The Essential Federalist and Anti-Federalist Papers (Indianapolis, 2003).

${ }^{61}$ D.L. Holmes, The Faiths of the Founding Fathers (Oxford, 2006).

${ }^{62}$ Cf. C. Kidd, 'Civil theology and church establishments in Revolutionary America', Historical Journal 42 (1999), 1007-26; V. Munoz, God and the Founders (Cambridge, 2009).

${ }^{63}$ Cf. L.W. Levy, The Establishment Clause: Religion and the First Amendment (New York, 1986).

${ }^{64}$ Cf. T.J. Curry, The First Freedoms: Church and State in America to the Passage of the First Amendment (Oxford, 1986); G.V. Bradley, Church-state Relationships in America (Westport CT, 1987).
} 
work of Henry May in the $1970 s^{65}$ - was, it seems, a multi-vocal conversation in which the most sceptical and radical voices were largely drowned out by the cautious and far-from-subversive incrementalism of a dominant Moderate-Didactic Enlightenment, which attempted to reconcile reason and Biblical revelation under the auspices of an updated rational Christianity. The concept of Enlightenment is itself a snare for the unwary, ${ }^{66}$ and category errors are to be found at work on both sides of the liberal-conservative divide.

Indeed, it should be clear by now that conservatism does not map easily onto originalism. Just as originalism is not a single phenomenon, but, as we have seen, stands shorthand for a variety of originalist perspectives, so too American conservatism is a very broad church, with a considerable amount of bickering in the aisles. There is no consensus among conservatives about the basic contours of America's constitutional history. Different groups of conservatives advance strongly divergent schemes of periodization and invoke strikingly different usable pasts.

Libertarian originalists do not regard the overreach of the Warren and Burger Courts as the major wrong-turning in American jurisprudence; they locate it earlier in the abandonment of strict laissez-faire doctrine - what is sometimes described as Lochnerism ${ }^{67}$ - on the New Deal Court from West Coast Hotels v Parrish (1937) onwards and enshrined in the celebrated footnote to the Carolene Products decision of 1938, which set out the standards of scrutiny for judicial review of legislation. ${ }^{68}$ The post-Carolene situation is described by leading libertarian conservatives as the era of 'the Lost Constitution ${ }^{69}$ or 'the Constitution in Exile', ${ }^{70}$ and they promote a radical restorationist approach to the law. Randy Barnett (b. 1952) has attacked Scalia's concessions to the demands of stare decisis, for 'invoking the precedents established by the dead hand of nonoriginalist justices' ${ }^{71}$ Libertarians have little truck with the social conservatism of Thomas and Scalia, which is indebted to Catholic natural law standards. The libertarian end of the conservative movement favours - with seeming ideological promiscuity - abortion rights, drug use, guns and unrestricted property rights. Libertarians locate these freedoms in the rarely invoked Ninth Amendment: 'The enumeration, in the Constitution, of certain rights, shall not be construed to deny or disparage others retained by the people.' Whereas for Bork the Ninth Amendment was an 'ink blot' whose imprecision left it void of legal meaning ${ }^{72}$ for Barnett it signified a general presumption of liberty behind the law, though one which the Court had quietly suppressed. According to Barnett, this is one of the seemingly obvious roads not taken in American jurisprudence. ${ }^{73}$ In particular, the 'privileges and immunities' clause of the Fourteenth Amendment ('The citizens of each State shall be entitled to all privileges and immunities of citizens of the several States.') was immediately gutted by the Supreme Court's narrow ruling on its scope in the Slaughterhouse cases (1873). One of the principal reasons why the liberal Court was tempted into an activist and sometimes, undeniably, arbitrary jurisprudence was the early neutering of 'privileges and immunities'. The Ninth Amendment and the 'privileges and immunities' clause were the dogs that did not bark in American legal history. Had they been implemented by the Courts as their framers had wanted, contended the ultra-originalist Barnett, then some of the central tensions in American jurisprudence would have been resolved without resort to judicial sleight of hand or accompanied by

\footnotetext{
${ }^{65}$ H.F. May, The Enlightenment in America (New York, 1976). See also R.A. Ferguson, The American Enlightenment 1750-1820 (Cambridge MA, 1997).

${ }^{66}$ Cf. R. Darnton, George Washington's False Teeth (New York, 2003).

${ }^{67}$ Cf. New York v Lochner 198 U.S. 45 (1905).

${ }^{68}$ U.S. v Carolene Products 304 U.S. 144 (1938).Henceforth the Court would defer to the legislative branch, but would apply stricter standards of scrutiny to legislation which appeared to violate Constitutional prohibitions, to distort the political process or to discriminate against minorities.

${ }^{69}$ R. Barnett, Restoring the Lost Constitution: the Presumption of Liberty (Princeton, 2004).

${ }^{70}$ A. Napolitano, The Constitution in Exile (Nashville TN, 2006).

${ }^{71}$ R. Barnett, 'Scalia's Infidelity: a Critique of "faint-hearted" Originalism', University of Cincinnati Law Review 75 (2006), 7-24, at 13.

${ }^{72}$ Shaffer (ed.), Bork Hearings, 106.

${ }^{73}$ See e.g. Barnett, Restoring; Barnett, 'The Ninth Amendment: It means what it says', Texas Law Review 85 (2006), 1-85.
} 
the howls of outrage from the social conservatives he regards as faux-originalists. However, by a further ironic twist, Thomas - from a markedly different ideological position - now shares Barnett's desire to revivify 'privileges and immunities'. ${ }^{74}$

There are other unexpected wrinkles in the fabric of conservative originalism. Significantly, the famous speech delivered by Attorney-General Meese announcing the arrival of a 'jurisprudence of original intention' was drafted by his chief speechwriter, later an eminent scholar, Gary McDowell, ${ }^{75}$ who belonged to the influential Straussian wing of the conservative movement. However, there is an incongruity here, for the Straussians ${ }^{76}$ - followers of the German émigré philosopher Leo Strauss (1899-1973) - tend to regard the Founding era with an awkward ambivalence singularly at odds with the conventional flag-waving norms of mainstream conservatism. The Straussians are proudly elitist, prizing their unconventionality and their privileged access to a strain of occult wisdom which their guru transmitted to his disciples over two decades at the University of Chicago between 1949 and 1969 , and was then passed from these disciples to subsequent generations of initiates. Straussian conservatives have tied themselves in knots over the years trying to reconcile American patriotism with a fastidious disdain for what - following the insights of Strauss - they identify as the base philosophy of the Founders. Instead the Straussians champion the high aspirations of the Ancients, and contend that philosophy took a wrong turning during the early modern era when it was perverted by the interest-based ethic of Machiavelli and Hobbes, ignoble philosophers who pandered to the lowest common denominator in humankind. It was, nevertheless, this soiled strain of early modern philosophy which, they contend, left its mark on the Framers' system of constitutional machinery. ${ }^{77}$

Martin Diamond (1919-77), a former socialist turned Straussian, found certain aspects of the Founding dispiriting. During the early modern era, the ancient notion of an all-encompassing 'polity' or 'regime' had given way to the diminished concept of 'government', to a politics of limited aspirations. Disappointingly, liberalism and modern republicanism were not 'the means by which men ascend to a nobler life'; rather they were 'simply instrumentalities which solve Hobbesean problems'. The Constitution and the Federalist were almost 'wholly silent' on 'the ends of government'. Whereas the Ancients had 'ranked highly, as objects of government, the nurturing of a particular religion, education, military courage, civic-spiritedness' and so forth, the American Founders made no 'special provision for excellence'. Had the Founders, perhaps, traded high ideals for mere political stability, a government of 'narrow ends'? Indeed, Diamond asked the very Straussian question: 'how might Aristotle rank America?' Diamond answered - with at least a hint of regret - that 'the new political science gave a primacy to the efficiency of means rather than to the nobility of ends'. The Constitution had nothing to do with 'ethical character formation'. Rather 'the American political system was deliberately tilted to resist, so to speak, the upward gravitational pull of politics toward the grand, dramatic, character-ennobling but society-wracking opinions about justice and virtue.' Nevertheless Diamond was able to contort his arguments into a far-from-resounding encomium upon the 'solid but low foundation of American life' in the Constitution. ${ }^{78}$

\footnotetext{
${ }^{74}$ See McDonald v City of Chicago, 561 U.S. 742 (2010).

${ }^{75}$ McDowell had previously proposed procedural solutions to tackle the problem of judicial overreach: see G. McDowell, ‘A modest remedy for judicial activism', Public Interest no. 67 (spring 1982), 3-20.

${ }^{76}$ For the Straussians, see - variously and subjectively - S. Drury, Leo Strauss and the American Right (New York, 1997); A. Norton, Leo Strauss and the Politics of American Empire (New Haven, 2004); M. Burnyeat, 'Sphinx without a secret', New York Review of Books (30 May 1985), 30-6; C. and M. Zuckert, The Truth about Leo Strauss (Chicago, 2006).

${ }^{77}$ K. L. Deutsch, 'Leo Strauss, the Straussians and the American Regime', in Deutsch and John A Murley (eds), Leo Strauss, the Straussians and the American Regime (Lanham MD, 1999), 51-67. Cf. P. Rahe, Republics Ancient and Modern: Classical Republicanism and the American Revolution (Chapel Hill, 1982).

${ }^{78}$ M. Diamond, 'Ethics and Politics: the American Way', in R.H. Horwitz (ed.), The Moral Foundations of the American Republic ( $3^{\text {rd }}$ edn., Charlottesville VA, 1986), 75-108, at 81, 92, 95; Diamond, 'Democracy and the Federalist', American Political Science Review 53 (1959), 52-68, at 62, 64, 66; Diamond, 'The Separation of Powers and the Mixed Regime' and 'The American Idea of Equality', both in W. Schambra (ed.), As far as Republican Principles will admit: Essays by Martin Diamond (Washington D.C., 1992), 63, 249.
} 
A more direct and less nuanced version of Diamond's complaint appears in the work of the conservative political commentator George F. Will (b. 1941), who popularised the Straussian critique of the Founders and the government they had created. Will castigated Reaganite conservatism as a variant of 'the liberal-democratic political impulse that was born with Machiavelli and Hobbes.' From these early modern bogeymen - the authors of 'the great redefinition' - there derived the modern political enterprise, a dismal project whose 'inadequacy' Will found 'glaring'. Now, instead of an Aristotelean conservatism founded upon the principle of 'what ought to be', there prevailed a scheme of politics which lowered human aspirations. It was a cause of lamentation that the 'founding philosophy' of the United States stated 'clearly and often, that public-spiritedness is unnatural.' In the Constitution and the Federalist the ideal of living 'optimally' had been suborned, replaced with the banal goal of 'regularity'. According to Will, true conservatism followed the lofty normative prescriptions of the Ancients, not the Moderns' descriptive accounts of the lowest common denominators in human nature. ${ }^{79}$

The Straussians have also played a major role in the rehabilitation of the opponents of the Constitution, the Anti-Federalists of 1787-91. Where previously Anti-Federalism had been written off as a kind of naysaying negativity without much substantive ideological content of its own, the insight of the Straussians brought into focus the positive message of the Anti-Federalists. In particular, Straussians recognised that Anti-Federalists articulated a version of the ancient vision of politics as a nursery of virtue and excellence. The central figure in the excavation and recovery of Anti-Federalist ideology was Herbert Storing (1928-77), a Straussian at the University of Chicago ${ }^{80}$ Storing published a pioneering monograph which mapped the ideological contours of Anti-Federalism and also anthologised Anti-Federalist writings ${ }^{81}$ The linkage between the Anti-Federalist espousal of ancient values and the true meaning of the Anti-Federalist inspired Bill of Rights can be glimpsed in the career of Walter Berns (1919-2015), an originalist, but of a distinctively Straussian cast. Berns favoured, for example, a reading of the establishment clause of the First Amendment which permitted support for religion in the States on a non-preferentialist basis. Surely, Berns reasoned, the Bill of Rights was not intended to restrict the operation of institutions which nourished civic virtue? ${ }^{82}$

The ambiguous status of the Constitution gave rise to an intra-Straussian civil war. While Diamond stood representative of the critical reading of the Constitution, Harry V. Jaffa (1918-2015) insisted that it was mistaken to decouple the Declaration of Independence from the Constitution, and contended that this double-bottomed version of the Founding embodied a high ethical purpose. ${ }^{83}$ However, Jaffa was at the patriotic extreme of the Straussian movement, and others questioned his reading of the Founding. Thomas Pangle, for instance, dismissed Jaffa as a vulgar myth-maker whose crude patriotism, which rested on 'thin poetry and compromised scholarship', betrayed the Straussian inheritance. ${ }^{84}$

Superficially there seems to be some congruence between the Straussian depiction of the Founders - the Anti-Federalists at least - and the historical recovery of classical republicanism. Ralph Lerner, a prominent disciple of Strauss, tellingly described the Supreme Court of the Founding era as 'a republican schoolmaster'. The federal judiciary played the part of 'statesmen-teachers' and 'Platonic Guardians', educating the citizenry in the values requisite for the support of republican self-

\footnotetext{
${ }^{79}$ G. F. Will, Statecraft as Soulcraft (1984), 23-4, 40-1, 159.

${ }^{80}$ M. Dry, 'Herbert Storing: the American Founding and the American Regime', in Deutsch and Murley (eds), Leo Strauss, 305-28.

${ }^{81}$ H. Storing, What the Antifederalists were for (Chicago, 1981); Storing (ed.), The Complete Anti-Federalist (7 vols, Chicago, 1981).

82 W. Berns, Freedom, Virtue and the First Amendment (Baton Rouge, LA, 1957); Berns, 'Religion and the founding principle', in R.H. Horwitz (ed.), The Moral Foundations of the American Republic ( $3^{\text {rd }}$ edn., Charlottesville VA, 1986), 204-29.

${ }^{83}$ H. V. Jaffa, 'In Defense of Political Philosophy', National Review (22 January 1982), 36-44, at 41; Jaffa, Original Intent and the Framers of the Constitution (Washington D.C., 1994).

${ }^{84}$ T. Pangle, 'Patriotism American Style', National Review (29 November 1985), 30-4, at 32.
} 
government. Lerner was characteristically - for a Straussian - grudging in his attitude towards the Federalists: 'how did the Framers expect to sustain and perpetuate a republican regime? The manner in which the Federalists addressed themselves to this question leaves much to be desired.' There was a glaring 'insufficiency' in 'muted' and 'incomplete' Federalist responses to Anti-Federalist charges about how republican virtue might be sustained.$^{85}$ However, any notional affinity between the Straussians and the republican turn in historiography turns out to be a mirage. The Straussians were critical of the attempts of historians to ground republican ideology in social context: ${ }^{86}$ Gordon Wood, for example, was pigeonholed among the category of 'quasi-Beardians' ${ }^{87}$ On the other hand Wood castigated the Straussians as 'sanctimonious' textual exegetes and quasi-priestly 'fundamentalists' who knew nothing of proper, context-oriented historical scholarship. ${ }^{88}$

Quirks and tensions of this sort provide merely a prologue to the complex relations between history and originalism. For the Founding era is but one in a succession of receding pasts which inform American Constitutional theory. In the centuries before the Constitution lie the vicissitudes of the English constitution and common law stretching back to Magna Carta, whose memorial at Runnymede was erected by the American Bar Association. Other layers sit between the late eighteenth century and today's topsoil. Arguably, the immediate post-Civil War era of the mid-1860s, not the late eighteenth-century Founding, provides the hinge on which most of modern constitutional jurisprudence turns, including its most vexing issues, such as substantive due process and the question of whether the Fourteenth Amendment incorporates the Bill of Rights. ${ }^{89}$ However, those are matters for another occasion.

The historical distortions which underpin originalism, and the misunderstandings to which it gives rise, present academic historians with major dilemmas. How far should historians divest themselves of their right - perhaps duty - to address the civic needs of the present? On the other hand, to what extent is the historical critique of originalist conclusions inflected by ideological as much as by methodological concerns, and as such to betray the ethos of the academy? Yet disinterested curiosity-driven history does suggest a tantalising third-way alternative to the crudely reductive ideologies of the culture wars, for the conservative enlightenment of late eighteenth-century America is not easily aligned with the values today of either Right or Left. Alas, sophisticated uncertainty of this sort lacks an audience outside the academy; and even those jurists most alert to the dangers of 'law office history' seek decisive answers to real-world legal problems, not a mess of caveats. ${ }^{90}$

\footnotetext{
${ }^{85}$ R. Lerner, 'The Supreme Court as Republican Schoolmaster', Supreme Court Review (1967), 127-80, at 1289, 156, 159-60.

86 T. Pangle, The Spirit of Modern Republicanism (Chicago, 1988), 36.

${ }^{87}$ M. Zuckert, 'Redefining the Founding: Martin Diamond, Leo Strauss and the American regime', in Deutsch and Murley (eds), Leo Strauss, 235-51, at 242. Charles Beard (1874-1948) had argued in An Economic Interpretation of the Constitution (New York, 1913) that the Constitution was a ploy to secure the property of financial-mercantile-creditor elites at the expense of indebted agrarian interests.

${ }^{88}$ G. Wood, 'The Fundamentalists and the Constitution', New York Review of Books (18 February 1988), 33-40.

${ }^{89}$ See amidst another vast literature, W.E. Nelson, The Fourteenth Amendment: From Political Principle to Judicial Doctrine (Cambridge MA, 1998).

${ }^{90}$ Cf. L.W. Levy, 'History and Original Intent', in Levy, Original Intent and the Framers' Constitution (Chicago, 1988), 313.
} 